\title{
PENGARUH PROMOSI, TERHADAP KEPUTUSAN PENGGUNAAN LAYANAN DIGITAL DIMEDIASI OLEH PENGETAHUAN KONSUMEN DAN KEPERCAYAAN KONSUMEN DI BANK SUMSEL BABEL CABANG PRABUMULIH
}

\author{
Omar Hendro \\ Magister Manajemen Universitas Muhammadiyah Palembang \\ Email: omarhendro@ymail.com \\ Diah Isnaini Asiati \\ Magister Manajemen Universitas Muhammadiyah Palembang \\ Email:diah_isnaini@yahoo.com \\ Dwi Puspita Sari \\ Magister Manajemen Universitas Muhammadiyah Palembang \\ Email:wikpus144@gmail.com
}

\begin{abstract}
This study aims to find out "The Influence of Promotion, Against the Decision on the Use of Digital Services Mediated by Consumer Knowledge and Consumer Confidence in the Babylon Bank of South Sumatra Branch". Problem formulation is a problem that will be answered by the research objectives. This study uses a statistical analysis tool that is multiple linear regression. The results of the calculation, the influence of each construct on the construct; first, Promotion has a positive and significant effect on Consumer Trust. The results of data analysis obtained a $t$-value of 27,182 with a t-table value of 1,965973. Second, Promotion has a significant effect on Consumer Knowledge. The results of data analysis obtained a t-value of 25.218 with a $t$-table value of 1.965973. This means that the Promotion variable has a significant effect on the Consumer Knowledge variable. Third, Consumer Trust has a positive and significant effect on Decision of Use. The results of data analysis obtained a $t$-value of 4.169 with a $t$-table value of 1.965973. Fourth, Consumer Knowledge has a positive and significant effect on Decision of Use. The results of data analysis obtained a value of $t$-value of 3.561 with a $t$-table value of 1.965973. Fifth, Promotion has a positive and significant effect on the Decision of Use. The results of data analysis obtained a t-value of 3.342 with a $t$-table value of 1.965973 . This means that the Promotion variable has a positive and significant effect on the Decision Use variable
\end{abstract}

Keywords: Promotion, Decisions on the Use of Digital Services, Consumer Knowledge and Consumer Trust. 


\section{Pendahuluan}

Salah satu kajian dalam pemasaran adalah perilaku konsumen. Perilaku Konsumen adalah tindakan-tindakan yang dilakukan oleh individu, kelompok atau organisasi yang berhubungan dengan proses pengambilan keputusan dalam mendapatkan, menggunakan barang-barang atau jasa ekonomis yang dipengaruhi lingkungan menurut Prabu Mangkunegara (2012: p,3). Ada tiga variabel dalam mempelajari perilaku konsumen, yaitu variabel stimulus, variabel respon, variabel antara (intervening). Perilaku konsumen mempelajari dimana, dalam kondisi macam apa, membeli suatu produk dengan merk tertentu.

Kesemuanya ini sangat membantu manajer pemasaran dalam menyusun kebijaksanaan pemasaran perusahaan. Proses pengambilan keputusan pembelian suatu barang atau jasa akan melibatkan berbagai pihak, sesuai dengan peran masing-masing. Peran yang dilakukan tersebut adalah 1). Initaiator yaitu individu mempunyai inisiatif untuk melalukan pembelian barang tertentu, 2). Influencer yaitu individu yang berpengaruh terhadap keputusan pembelian.Informasi mengenai kriteria yang diberikan akan dipertimbangkan baik secara sengaja atau tidak, 3). Decider yaitu individu yang memutuskan apakah akan membeli atau tidak, apa yang akan dibeli, bagaimana membelinya, 4).Buyeryaitu individu yang melakukan transaksi pembelian yang sesungguhnya, 5).User yaitu individu yang menggunakan barang atau jasa yang dibeli.

Perilaku konsumen yang didukung dengan kemajuan berbasis teknologi, sangat dirasakan sebagai suatu tantangan bagi industri perbankan.Salah satu bank yang dimaksud adalah Bank Sumsel Babel. Bank Sumsel Babel memerlukanrespon positif oleh konsumen dalam hal ini adalah nasabah terhadap layanan yang berbasis teknologi atau layanan digital perbankan,dengan kemajuan teknologi sangat penting bagi konsumen Bank Sumsel Babel untuk mengenal produk layanan digital tersebut sehingga pengetahuan konsumen mengenai layanan digital berperan dalam pengambilan keputusan penggunaan layanan digital di Bank Sumsel Babel .

Bank Sumsel Babel sebagai bank daerah yang terbesar di wilayah Sumatera Selatan sejak tahun 2000 sudah mempersiapkan infrastruktur untuk menuju bank dengan 
layanan terbaik di regionalnya. Bank Sumsel Babel yang terdiri dari: 1 Kantor Pusat, 28 Kantor Cabang, 51 Kantor Cabang Pembantu dan 97 Kantor Kas yang tersebar di seluruh wilayah sumbagsel, yang terdiri dari 2000 pegawai yang organik dan 500 pegawai non organik dan produk perbankan yang ada yaitu tabungan, giro dan kredit sedangkan produk layanan digitalnya antara lain: ATM, SMS Bangking, Internet Banking dan Phone Banking. Dari ke empat produk layanan digital penggunaan layanan digital SMS banking, internet banking dan Phone Banking masih dibawah $10 \%$ dari total nasabah keseluruhan sebanyak 685.690. data dapat dihat pada Tabel I.1

Tabel I.1

DATA NASABAH PENGGUNA LAYANAN DIGITAL PER 2017

\begin{tabular}{|r|r|r|r|r|r|}
\hline \multirow{2}{*}{ Nama Produk } & \multicolumn{2}{|c|}{ Seluruh Kantor } & \multicolumn{3}{|c|}{ KC Prabumulih } \\
\cline { 2 - 6 } & $\begin{array}{c}\text { Jumlah } \\
\text { Nasabah }\end{array}$ & Prosentase & \multirow{2}{*}{$\begin{array}{c}\text { Jumlah } \\
\text { Nasabah }\end{array}$} & & \multicolumn{2}{|c|}{ Prosentase } \\
\hline Total Nasabah & 685,690 & & 27,597 & & \\
\hline SMS Banking & 56,420 & 8.23 & 2,657 & 9.63 & 4.71 \\
\hline Internet Banking & 1,168 & 0.17 & 4 & 0.01 & 0.34 \\
\hline Phone Banking & 3,701 & 0.54 & 230 & 0.83 & 6.21 \\
\hline
\end{tabular}

Sumber: Data dari Bank Sumsel Babel Cabang Prabumulih, 2018

Produk layanan digital yang sudah diluncurkan oleh Bank Sumsel Babel untuk meningkatkan kepuasan konsumen dalam melakukan transaksi keuangan adalah: SMS banking, Internet banking, Phone Banking dan Kartu ATM/Debit. Berikut ditampilkan data pengguna layanan digital Bank Sumsel Babel pada Tabel 1.Namun demikian pada kenyataannya sampai dengan saat ini jumlah nasabah yang memanfaatkan layanan digital secara rata-rata masih dibawah 10\% untuk SMS Banking 8\%, Internet banking $0.017 \%$ dan Phone Banking 0,54\%. Berdasarkan data tersebut terlihat pengguna layanan digital masih dibawah 8,93\% atau 61.289 dari total nasabah 685.690 nasabah, hal ini menjadi suatu tantangan tersendiri bagi Bank Sumsel Babel untuk meningkatkan nasabah yang menggunakan layanan digital.

Berdasarkan hal tersebut, masih banyak nasabah yang belum memanfaatkan layanan digital. Bank Sumsel Babel Cabang Prabumulih juga, penggunaan layanan 


\section{Omar Hendro, Diah Isnaini Asiati, Dwi Puspita Sari, PENGARUH PROMOSI, TERHADAP KEPUTUSAN....}

digital juga masih sangat sedikit 10,47\% dari jumlah nasabah 27.597 dalam kondisi seperti ini Bank Sumsel Babel wilayah Prabumulih ini juga mempunyai kendala dalam peningkatan penggunaan layanan digital. Rendahnya pemanfaatan layanan digital tersebut disebabkan karena belum ada aktifitas promosi yang secara spesifik mendorong konsumen untuk bertransaksi lewat layanan digital. Bentuk promosi digital Bank Sumsel Babel Cabang Prabumulih yang selama ini dilakukan adalah, pertama, hadiah langsung hanya di berikan pada saat nasabah melakukan pembukaan rekening tabungan dengan jumlah nominal setoran awal diatas 5 juta. Kedua, Selanjutnya pemasaran langsung, hanya di lakukan secara langsung melalui custumer service. Ketiga, Iklan yang dilakukan hanya satu arah dengan melakukan promosi melalui pamplet,spanduk,siaran radio, belum ada jadwal khusus untuk melakukan kegiatan edukasi mengenai produk layanan digital itu sendiri sehingga informasi produk yang kurang detail dan kurang informatif diterima oleh nasabah pengguna atau pun yang belum menggunakan layanan digital.

\section{Kajian Teori}

\section{Perilaku Konsumen}

Menurut Basu Swasta, Handoko (2016; p10) Perilaku konsumen dapat didefinisikan sebagai kegiatan-kegiatan individu yang secara langsung terlibat dalam mendapatkan dan mempergunakan barang-barang dan jasa-jasa, termasuk didalamnya proses pengambilan keputusan pada persiapan dan penentuan kegiatan-kegiatan tersebut. Ada dua elemen penting dari arti perilaku konsumen itu: (1) proses pengambilan keputusan,dan (2) kegiatan fisik yang semuankegiatan-kegiatan tersebut. Ada dua elemen penting dari arti perilaku konsumen itu: (1) proses pengambilan keputusan,dan (2) kegiatan fisik yang semua ini melibatkan individu dalam menilai, mendapatkan, dan mempergunakan barang-barang dan jasa-jasa ekonomis. Menurut Kotler dan Keller (2008: p.214): Menurut Schiffman dan Kanuk (2008: p.6): Perilaku konsumen menggambarkan cara individu mengambil keputusan untuk memanfaatkan sumber daya mereka yang tersedia (waktu, uang,usaha) guna membeli barang-barang yang berhubungan dengan konsumsi. 
Tabel 1

Model Perilaku Konsumen

\begin{tabular}{|c|c|c|c|c|}
\hline $\begin{array}{l}\text { Rangsangan } \\
\text { Pemasaran }\end{array}$ & $\begin{array}{c}\text { Rangsangan } \\
\text { lainnya }\end{array}$ & $\begin{array}{l}\text { Ciri Ciri } \\
\text { Pembeli }\end{array}$ & $\begin{array}{l}\text { Proses Keputusan } \\
\text { Pembelian }\end{array}$ & Keputusan Pembelian \\
\hline Produk & Ekonomi & Budaya & Pemahaman Masalah & Pemilihan Produk \\
\hline Harga & Teknologi & Sosial & Pencarian Informasi & Pemilihan Merk \\
\hline Saluran Pemasaran & Politik & Pribadi & Pemilihan Alternatif & Pemilihan Saluran Pembelian \\
\hline Promosi & Budaya & Psikologi & Keputusan Pembelian & Penentuan Waktu Pembelian \\
\hline & & & Perilaku Pasca Pembelian & Jumlah Pembelian \\
\hline
\end{tabular}

\section{Keputusan Pembelian}

Keputusan pembelian yaitu sebuah pendekatan penyelesaian masalah pada kegiatan manusia untuk membeli suatu barang atau jasa dalam memenuhi keinginan dan kebutuhannya yang terdiri dari pengenalan kebutuhan dan keinginan, pencarian informasi, evaluasi terhadap alternatif pembelian, keputusan pembelian dan tingkah laku setelah pembelian (Swastha, 2009: p.68). Swastha dan Handoko (2016:p.103). Perilaku konsumen akanmenentukan proses pengambilan keputusan dalam pembelian mereka.

Menurut Schiffman dan Kanuk (2009: p.112), keputusan pembelian yaitu pemilihan dari dua atau lebih alternatif pilihan keputusan pembelian, artinya bahwa seseorang bisa membuat keputusan, harus tersedia beberapa alternatif pilihan. Keputusan untuk membeli bisa mengarah pada bagaimana proses dalam pengambilan keputusan tersebut itu dilakukan.

\section{Kepercayaan Konsumen.}

Menurut Sheth (2004) yang dikutip oleh ujang suwarman (2011,p.165) mendefinisikan kepercayaan sebagai berikut "Trust is a willingness to rely on the ability, integrity and motivation of the other party to act to serve the needs and interests as a agreed upon implicitly or explicitly". Kepercayaan adalah elemen dasar pembangunan model relationship quality.kepercayaan adalah keyakinan bahwa P-ISSN : 2460-9595

DOI. 10.36908/isbank.v5i2.117 


\section{8}

Omar Hendro, Diah Isnaini Asiati, Dwi Puspita Sari, PENGARUH PROMOSI, TERHADAP KEPUTUSAN....

pasangan dalam sebuah hubungan akan melakukan yang terbaik untuk apa yang diinginkan pasangannya menurut Sheth (2004) yang dikutip oleh ujang suwarman (2011,p.165). Dapat disimpulkan bahwa kepercayaan adalah faktor dasar yang membangun model relationship qualitydan juga merupakan keyakinan akan sebuah hubungan terhadap pasangan melakukan yang terbaik untuk apa yang dibutuhkan pasangan.

Pengertian kepercayaan tersebut memiliki beberapa hal penting sebagai berikut:

a. Konsumen yang memiliki kepercayaan akan bersedia untuk bergantung pada penyedia jasa dan juga bersedia untuk melakukan tindakan untuk penyedia jasa.

b. Kepercayaan memiliki tiga aspek dari karakteristik penyedia jasa yaitu ability, integrity, motivation.

c. Pihak yang dipercaya akan menjaga pihak yang lain, memperlihatkan kebutuhan dan harapan pihak lain tersebut, bukan hanya memperlihatkan kebutuhan dan harapannya sendiri.

\section{Pengetahuan Konsumen}

Menurut Mowen dan Minor (2012: p,56) Pengetahuan adalah " The amount of experience with and information about particular products or services person has.".atau pengetahuan adalah sejumlah pengalaman dengan berbagai macam informasi tentang produk atau jasa tertetu yang dimiliki. Sedangkan menurut Engel, Blackwell adn Miniard (2010: p,105 ) “ At a general level, knowledge can be defined as the informatioan stored within memory. The subset of total information relevant to consumers functioning in the market places is called consumer knowlwdge. "Atau Pada suatu tingkatan yang umum, pengetahuan dapat digambarkan sebagai informasi yang disimpan dalam memori. Himpunan informasi total yang relevan dengan fungsi konsumen di pasar.

\section{Penelitian Sebelumnya}

Eko Yuliawan. (2011) Pengaruh Pengetahuan Konsumen Mengenai Perbankan Syariah Terhadap Keputusan Menjadi Nasabah Pada Pt. Bank Syariah Cabang 
Bandung. Hasil penelitiannya, 1. Pengetahuan konsumen dengan indikator pengetahuan tentang karakteristik atau atribut produk atau jasa, 2. Keputusan konsumen dengan indikator pengenalan masalah, pencarian informasi, evaluasi alternatif dan keputusan pembelian berada dalam kategori menentukan terhadap pengambilan keputusan. 3 . pengetahuan konsumen berpengaruh terhadap keputusan konsumen sebesar $44.8 \%$.

Anggita Novita G,Lotje Kawet dan Yantje Uhing (2015) Analisis Motivasi, Persepsi, dan Pengetahuan Terhadap Keputusan Nasabah Memilih PT.Bank Sulutgo Cabang Utama Manado. Hasil penelitian 1.Variabel Motovasi, Persepsi, Pengetahuan secara simultan berpengaruh signifikan terhadap Keputusan Nasabah dalam memilih PT. Bank Sulutgo Cabang Utama Manado. 2.Motivasidan Pengetahuan secara parsial berpengaruh signifikan terhadap keputusan Nasabah dalam memilih PT Bank SulutGo Cabang Utama Manado. 3.Persepsi secara parsial tidak berpengaruh signifikan terhadap Keputusan Nasabah dalam memilih PT.BankSulutGo Cabang Utama Manado.

Yelli Trisusanti (2017) Pengaruh Kualitas Pelayanan dan Kepercayaan Terhadap Loyalitas Nasabah ( studi pada Bank BNI syariah Kantorr Cabang Pekanbaru) hasil penelitiannya Kualitas pelayanan pada Bank BNI Syariah Kantor cabang Pekanbaru berpengaruh signifikan terhadap loyalitas Nasabah. Kepercayaan pada Bank BNI Syariah kantor cabang pekanbaru berpengaruh signifikan terhadap loyalitas nasabah Kualitas pelayanan dan kepercayaan berpengaruh signifikan terhadap loyalitas nasabah.

Harwindra Yoga Prasetya dan Adi Nurmahdi (2017) Pengaruh Kegiatan Pemasaran Digital dan Perilaku Online Konsumen Pada Peningkatan Kesadaran Konsumen Dan Dampaknya TerhadapKeputusan Pembelian Via Website ( Studi Kasus Pada E-Commerce Website PT.Campina Ice Cream Industry) Pemasaran digital berpengaruh terhadap peningkatan kesadaran konsumen terhadap e-commerce website Campina Ice Cream. Pemasaran digitaldan perilkau konsumen secara online secara simultan berpengaruh terhadap keputusan pembelian di e- commerce websiteCampina Ice Cream.

Masagus M. Iqbal Syahputra (2016) Pengaruh bauran promosi terhadap keputusan menabung pada Tabungan Britama di PT. Bank BRI Kantor Cabang Tanjung Karang Bandar Lampung. Secara keseluruhan variabel periklanan, promosi penjualan dan P-ISSN : 2460-9595 
pemasaran langsung berpengaruh signifikan terhadap keputusan menabung pada tabungan BRITAMA PT Bank Rakyat Indonesia Cabang Tanjung Karang Bandar Lampung .

Wiwiek Rabiatul Adawiyah (2010) Pertimbangan, Pengetahuan, Dan Sikap Konsumen Individu Terhadap Bank Syariah.di Banyumas Purwokerto. Penelitian ini menghasilkan 1.Faktor yang paling dominan di pertimbangan konsupernmen dalam memilih Bank Syariah banyumas purwokerto adalah faktor persepsi 2,Pengetahuan Konsumen terhadap Bank Syariah masih terbatas. 3.Sebagian besar konsumen setuju dengan pernyataan bahwa penetapan bunga awal pinjaman dihapuskan seperti prinsipnya bagi hasil antara bank dan peminjam.

Asmat Dae (2017) Pengaruh Promosi dan Pengetahuan Konsumen Terhadap Keputusan Menjadi Anngota Bank Syariah di Bank Muamalat Kantor Cabang Pembantu Tulungagung. Hasil penelitian 1). Promosi berpengaruh positif terhadap keputusan menajadi anggota di Bank Muamala kantor Cabang Pembantu Tulunganung. 2). Pengetahuan konsumen berpengaruhi positif terhadap keputusan menjadi anggota di Bank Muamalat Capem Tulungangung. 3). Promosi dan Pengetahuan Konsumen secara bersama-sama berpengaruh positif terhadap keputusan menjadi anggota di Bank Muamalat Kantor Cabang Pembantu Tulungagung.

Muhammad Hidayatullah (2014) Pengaruh Pengetahuan Konsumen terhadap Keputusan Menjadi Nasabah Pada PT.Bank Syariah Bukopin Cabang Makasar. Hasil penelitian 1.Pengetahuan Komsumen yang terdiri dari atribut produk,manfaat produk, nilai kepuasan produk mempunyai pengaruh positif dan signifikan terhadap keputuisan nasabah dalam memilih Bnak Syariah di Makasar.2.Pengukuran Pengetahuan konsumen menunjukkan bahwa variabel yang dominan mempengaruhi keputusan konsumen dalam memilih Bank Syariah di Makasar adalah atribut produk .

\section{Kerangka Pemikiran}

Kerangka Pemikiran penelitian ini untuk mengetahui hubungan variabel bebas berupa Promosi melalui Pengetahuan Nasabah dan Kepercayaan Nasabah pada Keputusan Penggunaan sebagai variabel terikat, terlihat pada gambar II.2. 


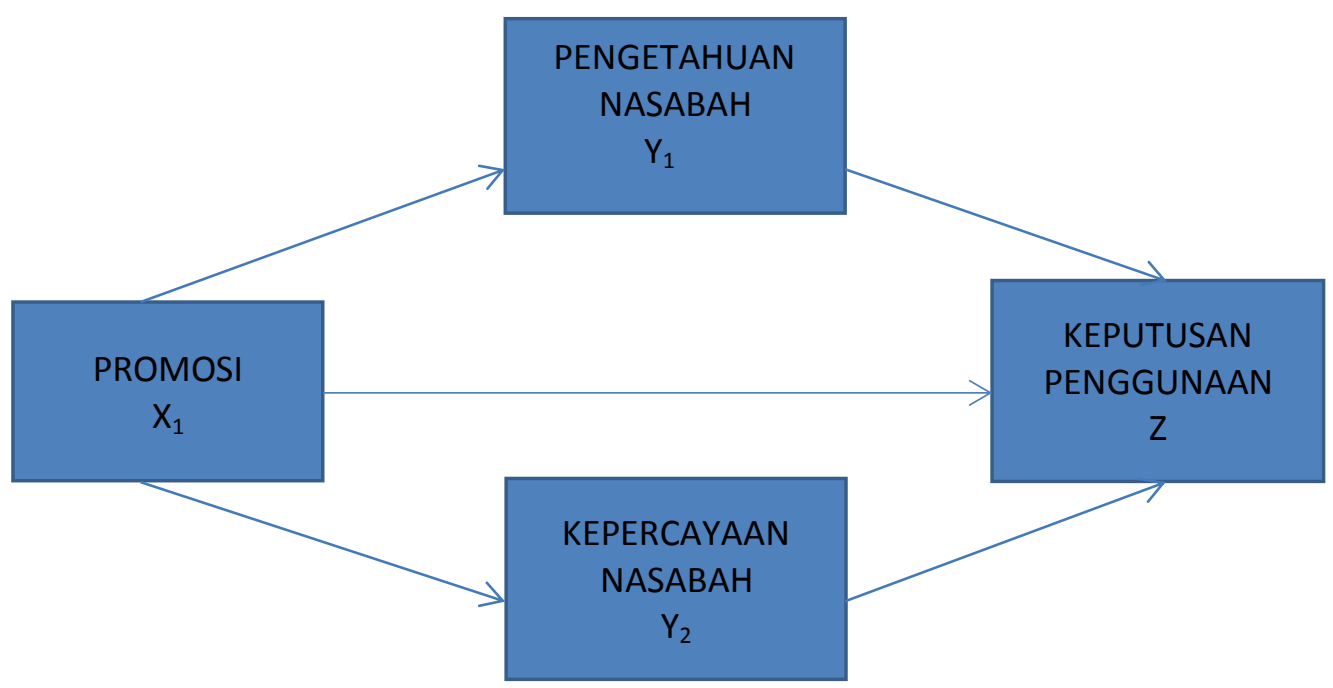

Gambar II.2

Kerangka Pemikiran

\section{Hipotesis}

1. Ada pengaruh Promosi, Pengetahuan Nasabah dan Kepercayaan Nasabah terhadap Pengambilan Keputusan penggunaan layanan digital di Bank Sumsel Babel Cabang Prabumulih.

2. Ada pengaruh Promosi terhadap Pengambilan Keputusan penggunaan layanan digital dengan Pengetahuan Nasabah sebagai variabel intervening di Bank Sumsel Babel Cabang Prabumulih.

3. Ada pengaruh Promosi terhadap Pengambilan Keputusan penggunaan layanan digital dengan Kepercayaan Nasabah sebagai variabel intervening di Bank Sumsel Babel Cabang Prabumulih.

4. Ada pengaruh Promosi terhadap Pengambilan Keputusan penggunaan layanan digital di Bank Sumsel Babel Cabang Prabumulih.

\section{Metode Penelitian}

\section{Desain Penelitian}

Penentuan disain penelitian secara deskriptiif penelitian menemukan fakta dengan interpretasi yang tepat, sedangkan secara analitis penelitian berusaha melakukan 
pengujian hipotesis untuk memperoleh interpretasi tentang keterkaitan beberapa variabel.

\section{Data}

a) Jenis Data

Jenis data yang digunakan adalah penelitian kualitatif. Data kualitatif yang dimaksud berupa jawaban responden berdasarkan kuisioner yang diedarkan yang berbentuk kata-kata.Untuk keperluan analisis, data ini selanjutnya dikuantitatifkan agar dapat diolah lebih lanjut sehingga memberikan hasil yang dapat digeneralisasikan.

\section{b) Sumber Data}

Sumber data terdiri atas data primer dan data sekunder. Data primer dan data sekunder. Data primer diperoleh langsung dari responden Bank Sumsel Babel Cabang Prabumulih sebagai sumber data lewat kuesioner. Data Sekunder (Secondary Data) dalam penelitian ini berupa data nasabah yang sudah dan belummenggunakan layanan digital.

\section{Variabel}

\section{Tabel III.1}

\section{Definisi Variabel}

\begin{tabular}{|c|c|c|c|}
\hline Variabel & Definisi & Indikator & Skala \\
\hline $\begin{array}{l}\text { Keputusan } \\
\text { Penggunaan } \\
\text { (Z) }\end{array}$ & $\begin{array}{l}\text { Sebuah pendekatan penyelesaian masalah } \\
\text { pada kegiatan nasabah untuk melakukan } \\
\text { penggunaan layanan di Bank Sumsel } \\
\text { Babel dalam memenuhi keinginan dan } \\
\text { kebutuhannya. }\end{array}$ & $\begin{array}{l}\text { - Pemilihan produk } \\
\text { - Pemilihan Merek } \\
\text { - Pemilihan saluran } \\
\text { pembelian } \\
\text { - Pemilihan Waktu } \\
\text { Pembelian } \\
\end{array}$ & orinal \\
\hline $\begin{array}{l}\text { Kepercayaan } \\
\text { Nasabah } \\
\quad\left(\mathrm{Y}_{2}\right) \\
\text { (variable } \\
\text { Intervening) }\end{array}$ & $\begin{array}{l}\text { Faktor dasar yang membangun model } \\
\text { relationship quality dan juga merupakan } \\
\text { keyakinan akan sebuah hubungan Bank } \\
\text { Sumsel Babel terhadap nasabah } \\
\text { denganmelakukan yang terbaik untuk apa } \\
\text { yang dibutuhkan nasabah tersebut. }\end{array}$ & $\begin{array}{l}\text { - Ability } \\
\text { - Integritas } \\
\text { - Motivasi }\end{array}$ & ordinal \\
\hline $\begin{array}{l}\text { Pengetahuan } \\
\text { Nasabah } \\
\quad\left(\mathrm{Y}_{1}\right) \\
\text { (variable } \\
\text { Intervening) }\end{array}$ & $\begin{array}{l}\text { Informasi yang dimiliki nasabah } \\
\text { mengenai berbagai macam produk Bank } \\
\text { Sumsel Babel, serta pengetahuan lainnya } \\
\text { yang terkait. }\end{array}$ & $\begin{array}{l}\text { - Pengetahuan Produk } \\
\text { - Pengetahuan Pembeli } \\
\text { - Pengetahuan } \\
\text { Pemakaian }\end{array}$ & ordinal \\
\hline $\begin{array}{c}\text { Promosi } \\
\left(\mathrm{X}_{1}\right)\end{array}$ & $\begin{array}{l}\text { Usaha Bank Sumsel Babeluntuk } \\
\text { menciptakan kesadaran, } \\
\text { memberitahukan,membujuk dan } \\
\text { mempengaruhi nasabah untuk melakukan } \\
\text { pembelian terhadap produk yang di } \\
\text { tawarkan. }\end{array}$ & $\begin{array}{l}\text { - Promosi Penjualan } \\
\text { - Pemasaran Langsung } \\
\text { - Periklanan } \\
\text { - Publik Relation }\end{array}$ & ordinal \\
\hline
\end{tabular}


Sumber : gagasan penulis dari berbagai teori relevan Kotler (2016); Griffin (2014); Basu Swasta,Handoko(2016); Ratih Huriyati (2015);Jasfar (2009); Prabu Mangkunegara: (2012).

\section{Populasi dan Sampel}

Populasi penelitian ini adalah seluruh nasabah Bank Sumsel Babel dengan dikelompokkan terdiri dari beberapa wilayah kecamatan di Prabumulih.

Tabel III.2.

Jumlah Nasabah BSB perwilayah kecamatan Prabumulih

\begin{tabular}{|c|l|c|}
\hline No. & Nama Kantor & Jumlah Nasabah \\
\hline $\mathbf{1 .}$ & Kantor Cabang Prabumulih & 13.610 \\
\hline $\mathbf{2 .}$ & Kantor Kas Pasar Prabumulih & 3.607 \\
\hline 3. & Kantor Kas RSUD Prabumulih & 1.487 \\
\hline $\mathbf{4 .}$ & Kantor Kas KPPT Prabumulih & 1.923 \\
\hline $\mathbf{5 .}$ & Kantor Kas PEMKOT Prabumulih & 650 \\
\hline $\mathbf{6 .}$ & Kantor Cabang Pembantu Gelumbang & 6.320 \\
\hline \multicolumn{2}{|c|}{ Total Nasabah } & $\mathbf{2 7 . 5 9 7}$ \\
\hline
\end{tabular}

Sumber :Data BSB Prabumulih, 2018

Dari Tabel III.2, total populasi dari 6 (enam) wilayah Kecamatan Prabumulih adalah 27.597.Jumlah sampel ditentukan mengunakan menggunakan rumus Isaac dan Michael.Sesuai dari tabel chi kuadrat untuk 27.597 populasi ditunjukan :

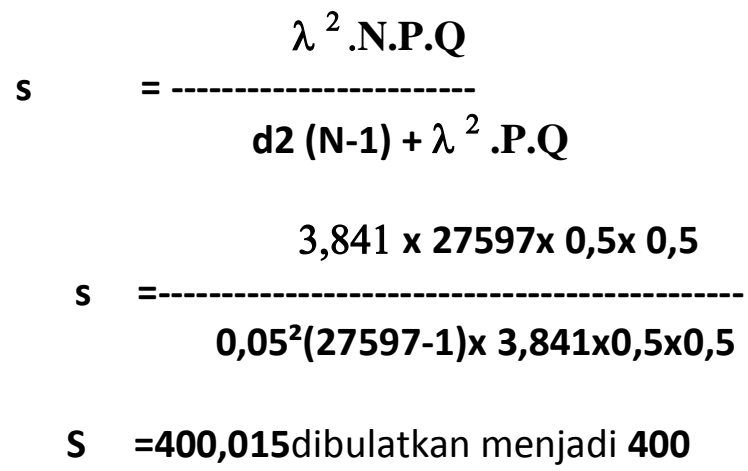

Dimana $\lambda^{2}$ dengan $\mathrm{dk}=1$, taraf kesalahan bisa $1 \%, 5 \%, 10 \% \mathrm{P}=\mathrm{Q}=0,5 \mathrm{~d}=0,05$ $\mathrm{s}=$ jumlah sampel

Keterangan:

$\mathrm{s} \quad=$ Jumlah sampel

$\lambda^{2}=$ Chi kuadrat yang hargannya tergantung derajat kebebasan 1 dan tingkat kesalahan 5\% harga chi kuadrat $=3,841$.lihat tabel chi kuadrat, tabel VI. 
$\mathrm{N}=$ Jumlah Populasi

$\mathrm{P} \quad=$ Peluang benar $(0,5)$

$\mathrm{Q}=$ Peluang salah $(0,5)$

$\mathrm{d}=$ Perbedaan antara sampel yang diharapkan dengan yang terjadi. Perbedaan bisa $1 \%, 5 \%$ dan $10 \%$

Dengan rumus tersebut didapat jumlah sampel yang akan diberikan kuesioner untuk penelitian ini sebanyak 400 nasabah dengan proporsi sebagai berikut:

Tabel III.3.

Jumlah Sampel Nasabah BSB perwilayah kecamatan Prabumulih

\begin{tabular}{|c|l|c|}
\hline No. & Nama Kantor & Jumlah Nasabah \\
\hline $\mathbf{1 .}$ & Kantor Cabang Prabumulih & 197 \\
\hline 2. & Kantor Kas Pasar Prabumulih & 52 \\
\hline 3. & Kantor Kas RSUD Prabumulih & 22 \\
\hline $\mathbf{4 .}$ & Kantor Kas KPPT Prabumulih & 28 \\
\hline $\mathbf{5 .}$ & Kantor Kas PEMKOT Prabumulih & 9 \\
\hline 6. & Kantor Cabang Pembantu Gelumbang & 92 \\
\hline \multicolumn{2}{r}{ Total Nasabah } & $\mathbf{4 0 0}$ \\
\hline
\end{tabular}

Sumber Data BSB Prabumulih, 2018.

Teknik sampling daerah digunakan untuk menentukan sampel bila objek yang akan diteliti atau sumber data sangat luas, misalnya penduduk dari suatu negara, propinsi atau kabupaten.

\section{Tehnik Pengumpulan Data}

Untuk pengumpulan data digunakan dengan cara dokumentasi dan kuesioner. Kuisioner yang disebar ke nasabah yang dijadikan sampel penelitian. Kuesioner yang digunakan dalam penelitian ini bersifat tertutup, yaitu responden tinggal menjawab sesuai dengan pilihan jawaban yang telah disediakan.

\section{Instrumen Penelitian}

\section{a) Uji Validitas}

Dasar pengambilan keputusan dalam uji validitas adalah, jika nilai $\mathrm{r}$ untuk $\mathrm{N}=30$ dengan tarif signifikan $5 \%$ adalah 0,361 .

1) Apabila $r h>$ dari 0,361 maka butir pertanyaan dinyatakan valid.

2) Apabila nilai $\mathrm{r} h \leq$ dari 0,361 maka butir pertanyaan dinyatakan valid. Uji validitas akan dilakukan dengan menyebarkan kusioner ke 30 nasabah Bank Sumsel Babel Cabang Prabumulih dan hasil uji validitas ini pada 30 nasabah tersebut akan dimasukkan dalam sampel 400 nasabah . 


\section{b) Uji Reliabilitas}

Teknik reliabilitas digunakan dalam penelitian ini adalah cronbach's Alpha $(\alpha)$. Mencari reliabilitas instrument yang skornya bukan 0-1, tetapi merupakan rentangan beberapa nilai, misalnya 0-10 atau 0-100 atau bentuk skala 1-3, 1-5, 1-7, dan seterusnya dapat menggunakan rumus cronbach's $A \operatorname{lph} a(\alpha)>0.60$.

\section{Metode Analisis}

\section{a) Analisis Statistik Deskriptif}

Analisis statistik deskriptif merupakan teknik analisis yang menggambarkan data yang telah dikumpulkan secara deskriptif sehingga dapat dibuat kesimpulan secara umum tanpa menguraikan hubungan, menguji hipotesis, bahkan penarikan kesimpulan untuk generalisasi.Analisis deskriptif yang digunakan adalah analisis persentase. Analisis berdasarkan perhitungan persentasei, apabila persentase jawaban untuk skala 1 , 2, dan 3 secara kumulatif relatif kecil (kurang dari 1/3 atau 33,3\%) maka indikator tersebut dinilai baik atau positif. Akan tetapi apabila secara kumulatif $\geq 33,3 \%$ maka indikator tersebut dinilai bermasalah sehingga perlu ditindaklanjuti dengan melakukan pembahasan secara lebih mendalam.

\section{b) Analisis Statistik Inferensial}

Pengujian verifikatif menggunakan alat statistik inferesial. Statistik inferensial dalam penelitian ini digunakan untuk melakukan pengujian hipotesis. Model path analysis digunakan untuk menganalisis pola hubungan antar variabel dengan tujuan untuk mengetahui pengaruh langsung maupun tidak langsung seperangkat variabel bebas (eksogen) terhadap variaabel terikat (endogen) (Buchari Alma, 2010: p.140).

Model persamaan strukturalnya dapat ditampilkan sebagai berikut:

$$
\mathrm{Z}_{1}=\mathbf{P}_{\mathrm{ZX} 1} \cdot \mathbf{X}_{1}+\mathbf{P}_{\mathrm{ZY} 1} \cdot \mathbf{Y}_{1}+\mathbf{P}_{\mathrm{ZY} 2} \cdot \mathbf{Y}_{2}+e_{1}
$$

\section{Hasil dan Pembahasan}

1. Hasil Analisis Jalur

Analisis path analysis dilakukan untuk melihat pengaruh Promosi $\left(\mathrm{X}_{1}\right)$, Pengetahuan Nasabah $\left(\mathrm{Y}_{1}\right)$, Kepercayaan Nasabah $\left(\mathrm{Y}_{2}\right)$ terhadap Keputusan 
86 Omar Hendro, Diah Isnaini Asiati, Dwi Puspita Sari, PENGARUH PROMOSI, TERHADAP KEPUTUSAN....

Penggunaan (Z). Berdasarkan hasil pengujian dengan bantuan program AMOS Versi 22.00 diperoleh hasil uji path analysis pada Model Pertama yaitu :

\section{Tabel.IV.1}

Hasil Analisis Path Analysis pada Model Pertama

Regression Weights: (Group number 1 - Default model)

\begin{tabular}{|c|c|c|c|c|c|c|c|}
\hline & & & Estimate & S.E. & C.R. & $\mathrm{P}$ & Label \\
\hline Rerata_Y1 & $<--$ & Rerata_X1 & .844 & .033 & 25.218 & $* * *$ & par_4 \\
\hline Rerata_Y2 & $<--$ & Rerata_X1 & .863 & .032 & 27.182 & $* * *$ & par_5 \\
\hline Rerata_Z1 & $<--$ & Rerata_Y1 & .225 & .063 & 3.561 & $* * *$ & par_1 \\
\hline Rerata_Z1 & $<--$ & Rerata_Y2 & .278 & .067 & 4.169 & $* * *$ & par_2 \\
\hline Rerata_Z1 & $<--$ & Rerata_X1 & .204 & .061 & 3.342 & $* * *$ & par_3 \\
\hline
\end{tabular}

Sumber: Olahan Peneliti, 2018.

Berdasarkan perhitungan seperti pada Tabel IV.1., diperoleh nilai Beta masingmasing variabel yaitu nilai Beta variabel Promosi $\left(\mathrm{X}_{1}\right)$ menuju Keputusan Penggunaan (Z) sebesar 0,204, nilai Beta variabel Pengetahuan Nasabah ( $\left.\mathrm{Y}_{1}\right)$ menuju Keputusan Penggunaan (Z) sebesar 0,225, Beta variabel Kepercayaan Nasabah $\left(\mathrm{Y}_{2}\right)$ menuju Keputusan Penggunaan $(Z)$ sebesar 0,278. Sehingga dapat dibentuk suatu persamaan path analysis pada Model Pertama, yaitu sebagai berikut:

$$
\begin{gathered}
\mathrm{Z}_{1}=\mathbf{P}_{\mathrm{ZX} 1} \cdot \mathrm{X}_{1}+\mathbf{P}_{\mathrm{ZY} 1} \cdot \mathrm{Y}_{1}+\mathbf{P}_{\mathrm{ZY} 2 \cdot \mathrm{Y}_{2}+e_{1}} \\
\mathrm{Z}_{1}=\mathbf{0 , 2 0 4 X _ { 1 }}+\mathbf{0 , 2 2 5} \mathrm{Y}_{1}+\mathbf{0 , 2 7 8 Y _ { 2 }}
\end{gathered}
$$

Berdasarkan persamaan path analysis di atas, maka berikut ini akan diinterpretasikan pengaruh masing-masing variabel bebas terhadap variabel terikat, yaitu sebagai berikut:

1. Nilai Beta variabel Promosi $\left(\mathrm{X}_{1}\right)$ menuju Keputusan Penggunaan $(\mathrm{Z})$ berarti sebesar 0,204, hal tersebut berarti bahwa variabel Promosi $\left(\mathrm{X}_{1}\right)$ mempengaruhi variabel Keputusan Penggunaan $\left(Z_{1}\right)$ (pengaruh langsung $\left.X_{1} \rightarrow Z_{1}\right)$ sebesar 0,204 (20,4\%), sehingga apabila terjadi peningkatan Promosi pada Keputusan Pengguna nasabah Bank Sumsel Babel Cabang Prabumulih., maka dapat mengakibatkan terjadinya peningkatan Keputusan Penggunaan. Sebaliknya apabila terjadi penurunan Promosi pada nasabah Bank Sumsel Babel Cabang Prabumulih., maka dapat mengakibatkan 
terjadinya penurunan Keputusan Penggunaan nasabah Bank Sumsel Babel Cabang Prabumulih.

2. Nilai Beta variabel Kepercayaan Nasabah $\left(\mathrm{Y}_{2}\right)$ menuju Keputusan Penggunaan $(\mathrm{Z})$ sebesar 0,278, berarti bahwa variabel Kepercayaan Nasabah $\left(\mathrm{Y}_{2}\right)$ mempengaruhi variabel Keputusan Penggunaan $\left(\mathrm{Z}_{1}\right)$ (pengaruh langsung $\mathrm{Y}_{2} \rightarrow \mathrm{Z}_{1}$ ) sebesar 0,278 $(27,8 \%)$, sehingga apabila terjadi peningkatan Kepercayaan Nasabah pada nasabah Bank Sumsel Babel Cabang Prabumulih, maka dapat mengakibatkan terjadinya peningkatan Keputusan Penggunaan. Sebaliknya apabila terjadi penurunan Kepercayaan Nasabah pada nasabah Bank Sumsel Babel Cabang Prabumulih, maka dapat mengakibatkan terjadinya penurunan Keputusan Penggunaan produk pada nasabah Bank Sumsel Babel Cabang Prabumulih.

3. Nilai Beta variabel Pengetahuan Nasabah $\left(\mathrm{Y}_{1}\right)$ menuju Keputusan Penggunaan $(\mathrm{Z})$ sebesar 0,225, berarti bahwa variabel Pengetahuan Nasabah $\left(\mathrm{Y}_{1}\right)$ mempengaruhi variabel Keputusan Penggunaan $\left(Z_{1}\right)$ (pengaruh langsung $Y_{1} \rightarrow Z_{1}$ ) sebesar 0,225 $(22,5 \%)$, sehingga apabila terjadi peningkatan Pengetahuan Nasabah pada nasabah Bank Sumsel Babel Cabang Prabumulih, maka dapat mengakibatkan terjadinya peningkatan Keputusan Penggunaan. Sebaliknya apabila terjadi penurunan Pengetahuan Nasabah pada nasabah Bank Sumsel Babel Cabang Prabumulih, maka dapat mengakibatkan terjadinya penurunan Keputusan Penggunaan produk pada nasabah Bank Sumsel Babel Cabang Prabumulih.

\section{Hasil Koefisien Determinasi}

Hasil koefisien determinasi ( $R$-Square) seperti yang dapat dilihat, dibawah ini:

Tabel IV.2

\section{Hasil Koefisien Determinan}

Model Summary

\begin{tabular}{|l|r|r|r|r|}
\hline Model & $\mathrm{R}$ & $\mathrm{R}$ Square & $\begin{array}{c}\text { Adjusted } \\
\text { R Square }\end{array}$ & $\begin{array}{c}\text { Std. Error of } \\
\text { the Estimate }\end{array}$ \\
\hline 1 & $.714^{\mathrm{a}}$ & .510 & .506 & .4893637 \\
\hline
\end{tabular}

a. Predictors: (Constant), Pengetahuan Konsumen, Promosi, Kepercay aan konsumen

Sumber: SPSS for Windows Versi 20.00. 
Pada Tabel IV.2., diperoleh nilai AdjustedR-Square (koefisien determinasi) sebesar 0,506. Berdasarkan besarnya koefisien determinasi tersebut dapat disimpulkan bahwa Keputusan Penggunaan $\left(\mathrm{Z}_{1}\right)$ pada nasabah Bank Sumsel Babel Cabang Prabumulih dapat dijelaskan oleh Promosi $\left(\mathrm{X}_{1}\right)$, Pengetahuan Nasabah $\left(\mathrm{Y}_{1}\right)$ Kepercayaan Nasabah $\left(\mathrm{Y}_{2}\right)$ sebesar 0,506 (50,6\%); sedangkan sisanya sebesar 0,494 (49,4\%) dijelaskan oleh faktor-faktor lain yang tidak masuk ke dalam penelitian ini $\left(e_{1}=0,494\right)$, misalnya kompensasi, kepuasan kerja, semangat kerja, beban kerja, loyalitas, keselamatan dan kesehatan kerja, dan faktor-faktor yang lainnya.

\section{Hasil Uji Hipotesis}

Uji hipotesis yang dilakukan adalah uji secara bersama-sama dengan menggunakan uji Hipotesis F (Anova) dan pengujian secara parsial dengan menggunakan uji Hipotesis t.

\section{a) Hasil Pengujian Hipotesis F (Anova)}

Berdasarkan hasil pengujian dengan menggunakan bantuan program SPSS for Windows Versi 20.00, diperoleh Nilai F-hitung seperti yang dapat dilihat pada Tabel IV.3, dibawah ini:

Tabel IV.3

Hasil Uji Hipotesis F (Anova) pada Model Pertama ANOVA

\begin{tabular}{|ll|r|r|r|r|r|}
\hline \multicolumn{1}{|c|}{} & \multicolumn{1}{c|}{$\begin{array}{c}\text { Sum of } \\
\text { Model }\end{array}$} & Squares & df & Mean Square & \multicolumn{1}{c|}{$\mathrm{F}$} & Sig. \\
\hline 1 & Regression & 98.578 & 3 & 32.859 & 137.213 & $.000^{\mathrm{a}}$ \\
& Residual & 94.833 & 396 & .239 & & \\
& Total & 193.411 & 399 & & & \\
\hline
\end{tabular}

a. Predictors: (Constant), Pengetahuan Konsumen, Promosi, Kepercay aan konsumen

b. Dependent Variable: Keputusan Penggunaan

Sumber: Olahan Peneliti, 2018

Berdasarkan hasil perhitungan seperti pada Tabel IV.3, diperoleh nilai F-hitung sebesar 137,213 dengan tingkat signifikansi (Sig F) sebesar 0,000. Sedangkan F-tabel dengan taraf nyata sebesar $(\alpha)=5 \%(0,05)$ dan derajat kebebasan $\mathrm{df}=(\mathrm{n}-\mathrm{k}-1)=(400-2-$ 1) $=397$ dan pembilang $(\mathrm{k})=2, \mathrm{~F}_{\text {tabel }}=3,0184$. Sehingga nilai F-hitung $(137,213)>\mathrm{F}-$ tabel $(3,0184)$, didukung dengan nilai Sig $\mathrm{F}(0,000)<\alpha(0,05)$, maka $\mathrm{H}_{0}$ ditolak dan $\mathrm{Ha}$ P-ISSN : 2460-9595 
diterima, berarti ada pengaruh positif dan signifikan Promosi, Kepercayaan Nasabah dan Pengetahuan Nasabah secara bersama-sama terhadap Keputusan Penggunaan produk pada nasabah Bank Sumsel Babel Cabang Prabumulih.

\section{b) Hasil Uji Hipotesis t (Uji Parsial)}

Untuk menentukan nilai t-tabel, dengan taraf nyata $(\alpha)=5 \%(0,05)$, dan derajat kebebasan df $=(n-2)=(400-2)=398(5 \% ; 398)$, yaitu sebesar 1,9659. Berdasarkan hasil pengujian dengan menggunakan bantuan program AMOS Versi 22.00, seperti yang dapat di lihat pada Tabel IV.. Hasil Analisis Path Analysis.

\section{Tabel .IV.4}

Hasil Uji Hipotesis t (Uji Parsial) pada Model Pertama

Regression Weights: (Group number 1 - Default model)

\begin{tabular}{|lll|rrrrr|}
\hline & & Estimate & S.E. & C.R. & P & Label \\
\hline Rerata_Y1 & $<---$ & Rerata_X1 & .844 & .033 & 25.218 & $* * *$ & par_4 \\
Rerata_Y2 & $<---$ & Rerata_X1 & .863 & .032 & 27.182 & $* * *$ & par_5 \\
Rerata_Z1 & $<---$ & Rerata_Y1 & .225 & .063 & 3.561 & $* * *$ & par_1 \\
Rerata_Z1 & $<---$ & Rerata_Y2 & .278 & .067 & 4.169 & $* * *$ & par_2 \\
Rerata_Z1 & $<---$ & Rerata_X1 & .204 & .061 & 3.342 & $* * *$ & par_3 \\
\hline
\end{tabular}

Sumber: Olahan Peneliti, 2018.

Nilai $t_{\text {hitung }}$ variabel Promosi $\left(\mathrm{X}_{1}\right)$ menuju Keputusan Penggunaan $(\mathrm{Z})(3,342)>\mathrm{t}_{\text {tabel }}$ $(1,9659)$ atau Sig $\mathrm{t}(0,000)<\alpha(0,05)$; maka $\mathrm{H}_{0}$ ditolak dan Ha diterima, artinya ada pengaruh positif dan signifikan Promosi terhadap Keputusan Penggunaan produk pada nasabah Bank Sumsel Babel Cabang Prabumulih.

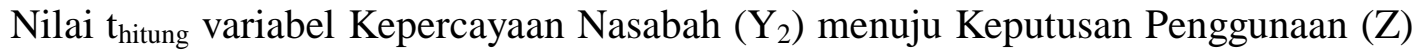
$(4,169)>t_{\text {tabel }}(1,9659)$ atau Sig-t $(0,000)<\alpha(0,05)$; maka $\mathrm{H}_{0}$ diterima dan Ha ditolak, artinya ada pengaruh positif dan signifikan antara Pengetahuan Nasabah terhadap Keputusan Penggunaan produk pada nasabah Bank Sumsel Babel Cabang Prabumulih.

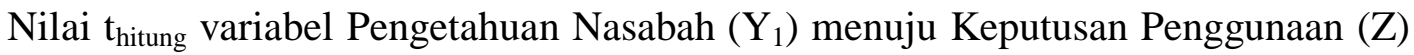
$(3,561)>t_{\text {tabel }}(1,9659)$ atau Sig-t $(0,000)<\alpha(0,05)$; maka $\mathrm{H}_{0}$ diterima dan Ha ditolak, artinya ada pengaruh positif dan signifikan antara Kepercayaan Nasabah terhadap 
90 | Omar Hendro, Diah Isnaini Asiati, Dwi Puspita Sari, PENGARUH PROMOSI, TERHADAP KEPUTUSAN....

Keputusan Penggunaan produk pada nasabah Bank Sumsel Babel Cabang Prabumulih. Secara diagram hasil pengolahan data dapat ditampilkan sebagai berikut:

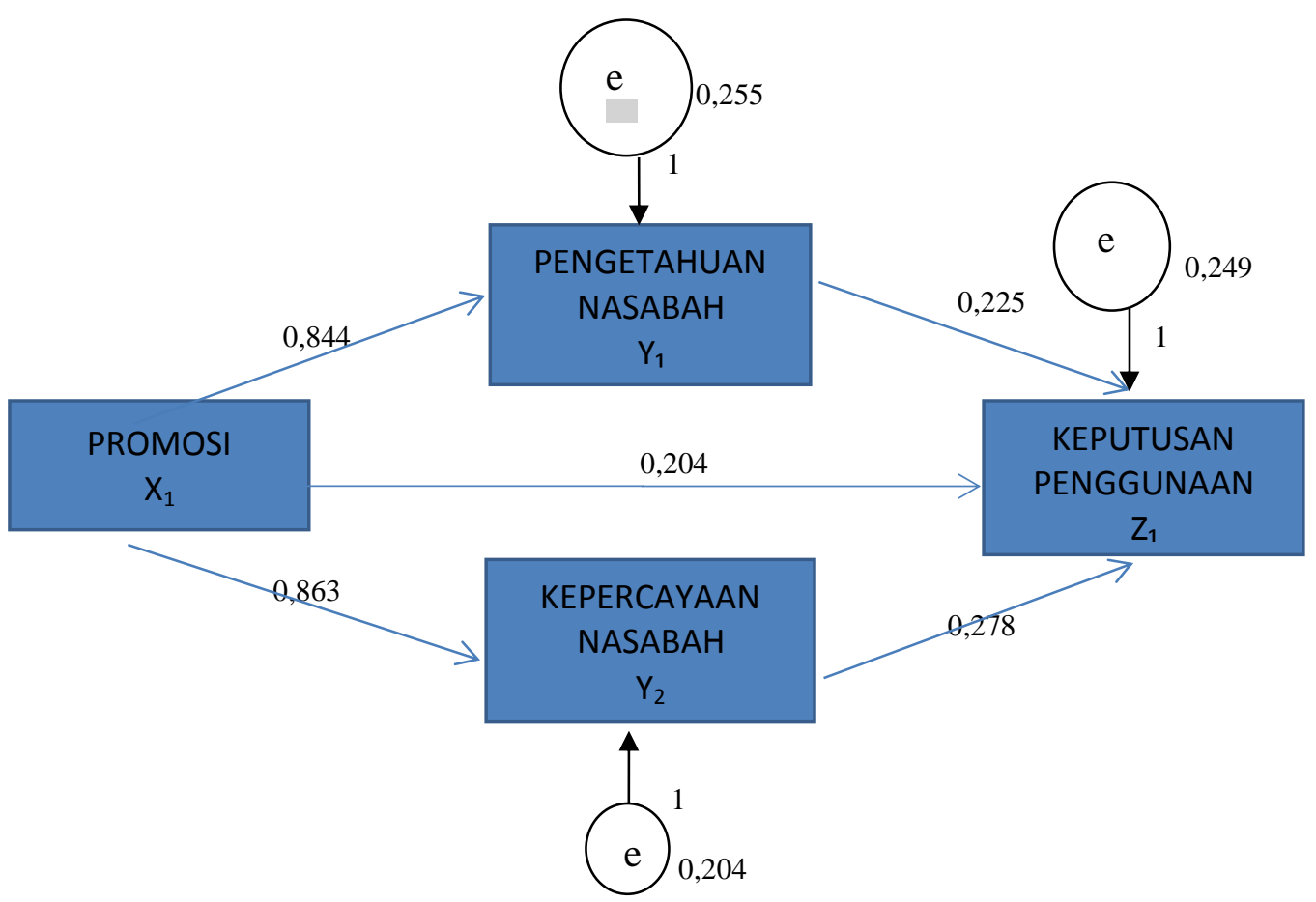

Sumber: Hasil Pengolahan Data Penulis, 2018

Gambar IV.1

Hasil Olahan Data Total

Hasil olahan data total pada penelitian ini akan disajikan dalam bentuk tabulasi data yang tersaji pada table berikut ini.

Tabel IV.5 Rangkuman Hasil Temuan Penelitian

\begin{tabular}{|c|c|c|c|}
\hline $\begin{array}{c}\text { Pengaruh antar } \\
\text { Variabel }\end{array}$ & $\begin{array}{c}\text { Pengaruh } \\
\text { Langsung }\end{array}$ & $\begin{array}{c}\text { Pengaruh Tidak } \\
\text { Langsung }\end{array}$ & Pengaruh Total \\
\hline $\mathbf{X} 1 \rightarrow$ Y1 & $\mathbf{0 , 8 4 4}$ & - & $\mathbf{0 , 8 4 4}$ \\
\hline $\mathbf{X} 1 \rightarrow$ Y2 & $\mathbf{0 , 8 6 3}$ & - & $\mathbf{0 , 8 6 3}$ \\
\hline Y1 $\rightarrow \mathbf{Z 1}$ & $\mathbf{0 , 2 2 5}$ & - & $\mathbf{0 , 2 2 5}$ \\
\hline Y2 $\rightarrow \mathbf{Z 1}$ & $\mathbf{0 , 2 7 8}$ & - & $\mathbf{0 , 2 7 8}$ \\
\hline $\mathbf{X 1} \rightarrow \mathbf{Z 1}$ & $\mathbf{0 , 2 0 4}$ & - & $\mathbf{0 , 2 0 4}$ \\
\hline P-ISSN $: 2460-9595$ & \multicolumn{2}{|c}{} & E-ISSN $: 2686-5149$
\end{tabular}

DOI. 10.36908/isbank.v5i2.117 
ISLAMIC BANKING Volume 5 Nomor 2 Edisi Februari $2020 \mid 91$

\begin{tabular}{|c|c|c|c|}
\hline $\mathrm{X} \rightarrow \mathrm{Y} 1 \rightarrow \mathrm{Z1}$ & $\mathbf{0 , 2 0 4}$ & $\mathbf{0 , 0 4 5 9}$ & $\mathbf{0 , 2 4 9 9}$ \\
\hline $\mathrm{X} \rightarrow \mathrm{Y} 2 \rightarrow \mathrm{Z1}$ & $\mathbf{0 , 2 0 4}$ & $\mathbf{0 , 0 5 6 7 1 2}$ & $\mathbf{0 , 2 6 0 7 1 2}$ \\
\hline
\end{tabular}

Sumber: Hasil Pengolahan Data Penulis, 2018 
Tabel IV.6

Rangkuman Hasil Hipotesis Temuan Penelitian

\begin{tabular}{|c|l|c|}
\hline No. & \multicolumn{1}{|c|}{ Hipotesis } & Hasil Temuan \\
\hline $\mathbf{1 .}$ & $\begin{array}{l}\text { Pengetahuan Nasabah berpengaruh signifikan } \\
\text { terhadap variabel Keputusan Penggunaan. }\end{array}$ & Ho ditolak \\
\hline $\mathbf{2 .}$ & $\begin{array}{l}\text { Promosi berpengaruh signifikan terhadap variabel } \\
\text { Keputusan Penggunaan }\end{array}$ & Ho ditolak \\
\hline 3. & $\begin{array}{l}\text { Kepercayaan Nasabah berpengaruh signifikan } \\
\text { terhadap variabel Keputusan Penggunaan }\end{array}$ & Ho ditolak \\
\hline 4. & $\begin{array}{l}\text { Promosi berpengaruh signifikan terhadap variabel } \\
\text { Pengetahuan Nasabah. }\end{array}$ & Ho ditolak \\
\hline 5. & $\begin{array}{l}\text { Promosi berpengaruh signifikan terhadap variabel } \\
\text { Kepercayaan Nasabah. }\end{array}$ & Ho ditolak \\
\hline
\end{tabular}

Sumber: Hasil Pengolahan Data Penulis, 2018

\section{Pembahasan}

1. Pengaruh Promosi $\left(\mathrm{X}_{1}\right)$, Pengetahuan Nasabah $\left(\mathrm{Y}_{1}\right)$, Kepercayaan Nasabah $\left(\mathrm{Y}_{2}\right)$ terhadap Keputusan Penggunaan layanan digital $\left(\mathrm{Z}_{1}\right)$.

Hasil analisis data menunjukkan bahwa variabel Pengaruh Promosi $\left(\mathrm{X}_{1}\right)$, Pengetahuan Nasabah $\left(\mathrm{Y}_{1}\right)$, Kepercayaan Nasabah $\left(\mathrm{Y}_{2}\right)$ berpengaruh signifikan terhadap variabel Keputusan Penggunaan layanan digital $\left(\mathrm{Z}_{1}\right)$. Hasil analisis data memperoleh semua variabel memiliki nilai sig. p-value $<0,05$, hal ini berarti variabel Pengaruh Promosi $\left(\mathrm{X}_{1}\right)$, Pengetahuan Nasabah $\left(\mathrm{Y}_{1}\right)$, Kepercayaan Nasabah $\left(\mathrm{Y}_{2}\right)$ berpengaruh signifikan terhadap variabel Keputusan Penggunaan layanan diigital $\left(\mathrm{Z}_{1}\right)$.

2. Pengaruh variabel Promosi $\left(\mathrm{X}_{1}\right)$ terhadap variabel Keputusan Penggunaan layanan digital $\left(\mathrm{Z}_{1}\right)$ melalui Pengetahuan Nasabah $\left(\mathrm{Y}_{1}\right)$. Hasil analisis data menunjukkan bahwa variabel Promosi $\left(\mathrm{X}_{1}\right)$ berpengaruh signifikan terhadap variabel Keputusan Penggunaan layanan digital $\left(\mathrm{Z}_{1}\right)$ melalui Pengetahuan Nasabah $\left(\mathrm{Y}_{1}\right)$. Secara langsung promosi berpengaruh signifikan terhadap keputusan penggunaan layanan digital. Secara tidak langsung (dengan variabel pengetahuan Nasabah sebagai variabel intervening) promosi juga berpengaruh terhadap keputusan penggunaan layana digital. Pengaruh promosi dengan intervening variabel pengetahuan nasabah $(0,2499)$ ternyata lebih besar dibandingkan pengaruh langsungnya $(0,204)$, dengan 
demikian pengetahuan nasabah merupakan variabel penyela (antara) yang terletak diantara promosi dan keputusan penggunaan layanan digital.

3. Pengaruh variabel Promosi $\left(\mathrm{X}_{1}\right)$ terhadap variabel Keputusan Penggunaan layanan digital $\left(\mathrm{Z}_{1}\right)$ melalui Kepercayaan Nasabah $\left(\mathrm{Y}_{2}\right)$.

Hasil analisis data menunjukkan bahwa pengaruh variabel Promosi $\left(\mathrm{X}_{1}\right)$ berpengaruh signifikan terhadap variabel Keputusan Penggunaan layanan digital $\left(\mathrm{Z}_{1}\right)$ melalui Kepercayaan Nasabah $\left(\mathrm{Y}_{2}\right)$. Secara langsung promosi berpengaruh signifikan terhadap keputusan penggunaan layanan digital. Secara tidak langsung (dengan variabel kepercayaan nasabah sebagai variabel intervening) promosi juga berpengaruh terhadap keputusan penggunaan layana digital. Pengaruh promosi dengan intervening variabel kepercayaan nasabah $(0,260712)$ ternyata lebih besar dibandingkan pengaruh langsungnya $(0,204)$. Dengan demikian kepercayaan nasabah merupakan variabel penyela (antara) yang terletak diantara promosi dan keputusan penggunaan layanan digital. Dengan demikian keputusan layanan digital tidak langsung berubah dengan adanya promosi, akan tetapi tergantung kemampuannya mengubah kepercayaan nasabah. Semakin banyak kepercayaan nasabah berubah akibat promosi, maka makin kuat keputusan nasabah menggunakan layanan digital

Dilihat berdasarkan jawaban responden pada (keputusan penggunaan layana digital), (kepercayaan nasabah), dan (Promosi) terdapat beberapa penjelasan lebih lanjut sebagai berikut:

a. Terhadap aktivitas promosi yang dilakukan perbankan, terdapat beberapa indikator yang memiliki nilai akumulasi jawaban > 33,3\%. Beberapa iklan Bank Sumsel tampaknya belum sepenuhnya sampai kepada konsumen. Untuk masalah ini sebaiknya Bank Sumsel melakukan evalusi terhadap aktivitas promosinya. Penting menekankan daya tarik dan berbagai kemudahan yang dapat diperoleh nasabah apabla bersedia melakukan layanan digital. Dengan demikian akan semakin banyak nasabah yang bersedia menggunakan layanan digital.

b. Terhadap kepercayaan nasabah, dilihat dari nilai akumulasinya tampaknya tidak ada masalah. Akan tetapi potensi masalah dapat saja timbul dari indikator-indikator P-ISSN : 2460-9595 
$94 \mid$ Omar Hendro, Diah Isnaini Asiati, Dwi Puspita Sari, PENGARUH PROMOSI, TERHADAP KEPUTUSAN....

yang memiliki jawaban kurang maksimal (relatif tinggi nilai netralnya). Dan ternyata jawaban netral tertinggi (23\% dan $22,8 \%$ ) ada pada pernyataan bahwa "layanan digital meningkatkan kepercayaan nasabah" dan "Bank Sumsel telah memerikan layanan digital dengan baik". Ini berarti nasabah memang belum sepenuhnya memiliki kepercayaan terhadap layanan digital yang diberikan oleh Bank Sumsel. Oleh karena itu Bank Sumsel sebaiknya melakukan edukasi untuk menumbuhkan kepercayaan nasabah sehingga nasabah bersedia melakukan transaksi digital.

\section{Simpulan}

Berdasarkan hasil analisis, maka dapat disimpulkan sebagai berikut:

1. Variabel Promosi, Pengetahuan Nasabah, dan Kepercayaan Nasabah berpengaruh positif terhadap Pengambilan Keputusan penggunaan layanan digital di Bank Sumsel Babel Cabang Prabumulih.

2. Variabel Promosi berpengaruh positif terhadap keputusan penggunaan layanan digital dengan pengetahuan nasabah sebagai variabel intervening di Bank Sumsel Babel Cabang Prabumulih.

3. Variabel Promosi berpengaruh positif terhadap keputusan penggunaan layanan digital dengan kepercayaan nasabah sebagai variabel intervening di Bank Sumsel Babel Cabang Prabumulih.

4. Promosi berpengaruh secara signifikan terhadap variabel Keputusan Penggunaan layanan digital di Bank Sumsel Babel Cabang Prabumulih.

Peneliti memberikan beberapa saran yaitu :

a). Bank Sumsel melakukan evaluasi terhadap aktivitas promosinya dengan teknik personal selling untuk meningkatkan pengetahuan nasabah.

b). Bank Sumsel juga dapat melakukan promosi edukasi terhadap manfaat layanan digital. 


\section{DAFTAR PUSTAKA}

Alfansi, Lizar, 2012. Pemasaran Jasa Finansial. Jakarta: Salemba Empat.

Alma,Buchari 2016. Manajemen Pemasaran dan Pemasaran Jasa. Penerbit Alfabeta, Bandung

Alma Buchari, 2010. Manajemen Pemasaran dan Pemasaran Jasa. Penerbit Alfabeta,Bandung

Andini, Suharyono dan Sunarti, 2014. Pengaruh Viral Marketing Terhadap Kepercayaan Pelanggan Dan Keputusan Pembelian (Studi Pada Mahasiswa Fakultas Ilmu Administrasi Univesitas Brawijaya Angkatan 2013 yang melakukan Pembelian Online Melalui Media Sosial Instagram). Jurnal Administrasi BisnisVol.11, Nomor 1, hal 1-6

Cant,M.,Strydom,J., Jooste, C.,\&Plessis, P.D. 2006. Marketing Management.(5th ed.). South Africa: Juta \& Company.

Christina WhidyaUtami, 2010.Manajemen Ritel (Edisi 2).Jakarta: Salemba Empat.

Citra Sugianto Putri, 2016, Pengaruh Media Sosial Terhadap Keputusan Pembelian Konsumen Cherie Melalui Minat Beli. Jurnal Manajemen dan Start-Up Bisnis, Vol 1 NO. 05 Des 2016. 594-603

Dharmmesta, Basu Swastha dan Handoko, T.Hani 2016. Manajemen Pemasaran Analisis Perilaku Konsumen. Penerbit BPFE-YOGYAKARTA, 2016

Eko Yuliawan, 2011. Pengaruh Pengetahuan Konsumen Mengenai Perbankan Syariah Terhadap Keputusan Menjadi Nasabah Pada PT. Bank Syariah Cabang Bandung, Jurnal Wira Ekonomi MIkroskil Volume 1, Nomor 01, April 2011.

Essinger,J.,\& Wylie, H. 2003. Customer strategy: Devising successful strategies in food and drink. Reuters Business Insight.

Fadilla, F., \& Aravik, H. 2018. Pandangan Islam dan Pengaruh Kurs, BI Rate terhadap Inflasi. Jurnal Ecoment Global; Kajian Bisnis dan Manajemen, 3(2), 95-108.

Grewal, Dhruv, \& Michael, L. 2010. Marketing, (2nd ed.). New York: McGrawHill.

Ghozali, I. 2005. Aplikasi Analisis Multivariate Dengan Program SPSS. Badan Penerbit Universitas Diponegoro. Semarang.

Griffin, 2005. Manajemen edisi 7 jilid 1.Penerbit Erlangga Ciracas,Jakarta

Harjanto, R. 2009. Prinsip-prinsip periklanan. Jakarta: PT Gramedia

Jasfar,F.2009. Manajemen Jasa Pendekatan Terpadu. Ghalia Indonesia Jakarta

Kotler dan Amstrong 2012. Prinsip-Prinsip Pemasaran. Edisi 13. Jilid 1. Jakarta: Erlangga 
$96 \mid$ Omar Hendro, Diah Isnaini Asiati, Dwi Puspita Sari, PENGARUH PROMOSI, TERHADAP KEPUTUSAN....

Kotler, P. \& Keller, K. L. 2012. Marketing management (14th ed.). United States of America : Pearson

Lupiyoadi,R. 2013. Manajemen pemasaran jasa berbasis kompetensi. (Edisi Ketiga.). Jakarta: Salemba Empat.

Madura,Jeff. 2011. Pengantar Bisnis .Penerbit Salemba Emapt edisi 4 buku 1 dan 2 Jakarta.

Morissan, 2010. Periklanan: KomunikasiPemasaran Terpadu. Bogor: Prenada

Nazir ,Moh. 2009. Metode Penelitian. Jakarta: Ghalia Indonesia.

Novita Ekasari, 2014. Pengaruh Promosi Berbasis Sosial Media Terhadap Keputusan Pembelian Produk Jasa Pembiayaan Kendaraan Pada PT.BFI Finance Jambi. Jurnal Penelitian Universitas Jambi Seri Humaniora Vol.16 Nomor 2, Juli-Des 2014 hal,81-102 ISSN:0852-8349

Prasetya dan Adi Nurmahdi. Pengaruh Kegiatan Pemasaran Digital Dan Perilaku Online Konsumen Pada Peningkatan Kesadaran Konsumen Dan Dampaknya Terhadap Keputusan Pembelian Via Website ( Studi Kasus Pada E-Commerce Website PT.Campina Ice Cream Industry).

Rangkuti, F. 2006. Riset Pemasaran. (5th ed.). Jakarta: Gramedia Pustaka Utama.

Saebani,Beni Ahmad, 2015. Perilaku Konsumen Teori dan Praktik. Penerbit: PustakaSetia,Bandung

Siagian,S.P. 2007. Manajemen Sumberdaya Manusia. (14th ed.). Jakarta: Penerbit Bumi Aksara.

Sugiyono. 2010. Metode Penelitian Kuantitatif Kualitatif dan R\&D. Bandung: Alfabeta

Sumarwan, Ujang .Perilaku Konsumen Teori dan Penerapannya dalam Pemasaran. Penerbit Ghalia Indonesia .Cet.Kedua, Februari 2014. Jl. Rancamaya Km. 1 No. 47, Warung Nangka, Ciawi - Bogor 16720

Sunyoto, Danang 2014. Praktik Riset Perilaku Konsumen. Penerbit: PT.BUKU SERU, Jakarta

Suyanto, Asep Herman. 2007. Web Design Theory and Practices.Yogyakarta: Andi

Swastha, B. Dharmmesta dan Handoko, T hani 2016. Manajemen Pemasaran ,Analiiss Konsumen. Edisi Pertama di cetak BPFE-Yogyakarta cetakan ketujuh agustus 2016

Tjiptono, F. 2014. Pemasaran Jasa. Penerbit Andi. Yogyakarta (Wyckof dalam Lovelock yang dikutip oleh Fandy Tjiptono, 2012) Konsep Kualitas Pelayanan Publik

Umar, Husein. 2010. Riset Pemasaran Dan Perilaku Konsumen. Penerbit PT.Gramedia Bulding, Jakarta

Yazid. 2003. Pemasaran Jasa, Edisi Kedua, Fakultas Ekonomi UII, Yogyakarta. 
Zeithaml, V.A., Bitner, M.J. \& Gremler, D.D. 2006. Service marketing. $4^{\text {th }}$ edition. New York: The MC Graw-Hill Companies, Inc.

Zamzam, Fakhry, Havis Aravik, 2016. Manajemen SDM Berbasis Syariah, Bogor: CV. RWTC Success. 
98 Omar Hendro, Diah Isnaini Asiati, Dwi Puspita Sari, PENGARUH PROMOSI, TERHADAP KEPUTUSAN.... 